\title{
Elizabethkingia miricola Recovered from a Peritoneal Fluid Sample - A Clinical Case Report with Diagnostic Challenges
}

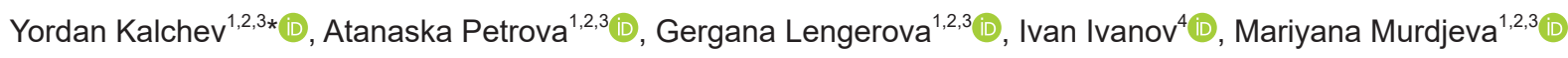 \\ ${ }^{1}$ Department of Microbiology and Immunology, Faculty of Pharmacy, Medical University - Plovdiv, Plovdiv, Bulgaria; ${ }^{2}$ Laboratory \\ of Microbiology, St. George University Hospital - Plovdiv, Plovdiv, Bulgaria; ${ }^{3}$ Department of Innovative Diagnostic Methods, \\ Research Institute at Medical University - Plovdiv, Plovdiv, Bulgaria; ${ }^{4}$ National Reference Laboratory for Control and Monitoring \\ of Antimicrobial Resistance, National Center of Infectious and Parasitic Diseases, Sofia, Bulgaria
}

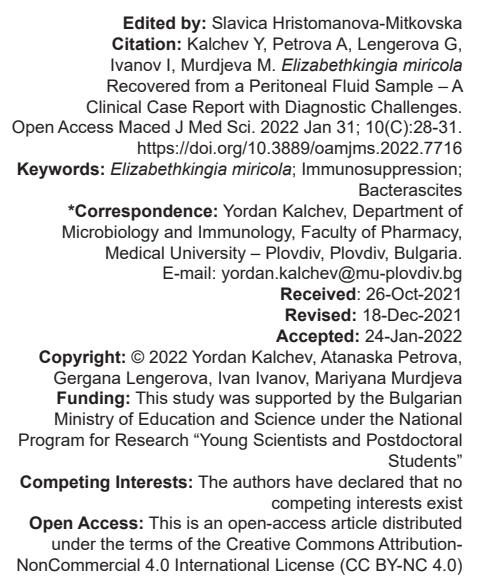

\section{Abstract}

BACKGROUND: Elizabethkingia spp. are Gram-negative, non-spore-forming bacteria that used to be rarely encountered but now they are of growing clinical significance. Furthermore, the diagnostic challenges to identification impede the complete elucidation of their epidemiology and association with human diseases.

CASE REPORT: A 64-year-old man with liver cirrhosis due to alcohol abuse presented with fatigue, abdominal swelling, and bilateral scrotal edema. A peritoneal fluid sample was cultured and subject to a number of identification methods - API 20 NE (bioMerieux), automated Vitek-2 Compact (bioMerieux), MALDI-TOF MS (Vitek-MS, bioMerieux), and 16S rRNA gene sequencing. A final diagnosis of bacterascites was made on the basis of clinical, laboratory, and microbiological findings.

CONCLUSION: To the best of our knowledge, this is the first report of Elizabethkingia miricola being cultured from a peritoneal fluid sample in an immunocompromised host thus pointing to the emerging pathogenic role of the bacterium in patients with liver cirrhosis and ascites.

\section{Introduction}

Elizabethkingia miricola is a rarely encountered Gram-negative non-fermentative bacterium. It was first isolated from the space station Mir, explaining its species name [1]. Since 2008 when the first case of human infection was reported, several more announcements have been made, describing the association of the microorganism with severe sepsis, lung abscess, urinary tract infections, cystic fibrosis, cancer, and humoral immunodeficiency [2], [3], [4], [5], [6], [7], [8]. All these records are demonstrating the potential of the bacterium to cause human infections, especially in immunocompromised hosts, thus making it an emerging human pathogen. Given the considerably challenging accurate identification, the global incidence of $E$. miricola infections is unknown and it is probably varying from geographical region to region. A study from South Korea reported an increased incidence of these infections from 0 to $0.22 / 1000$ admissions over the period of 2009-2016 [9]. The incidence of E. miricola in Bulgaria is undetermined. We report the first case of $E$. miricola isolated from the peritoneal fluid sample from a patient with liver cirrhosis and ascites. With the current case report, we aimed to draw attention to this emerging pathogen and its likely association with infections of the peritoneal cavity, to emphasize the diagnostic challenges to the microbiological laboratory, and also to extend the available scarce epidemiological data.

\section{Case Report}

A 64-year-old man presented to the Clinic of Gastroenterology, St. George University Hospital Plovdiv, with a general malaise, right upper quadrant discomfort, abdominal tenderness and swelling along with a bilateral scrotal edema. He reported alcohol overconsumption and being a non-smoker. Comorbidities included chronic ischemic heart disease and paroxysmal atrial fibrillation. 
On initial examination, the patient was hemodynamically stable. Respiratory system evaluation was unremarkable. Subicteric discoloration of the skin and sclerae was noted. Abdominal examination revealed a distended abdomen with normal peristalsis on auscultation and no hepatosplenomegaly was evident on palpation. Blumberg's sign was negative.

Chest X-ray was unremarkable. Abdominal ultrasonography demonstrated enlarged steatofibrotic liver with perihepatic and perisplenic fluid accumulation. The gallbladder, spleen, and kidneys showed no abnormalities. Esophagogastroduodenoscopy revealed esophageal varices and erosions of the gastric mucosa. Stomach biopsy tested negative for Helicobacter pylori.

Clinical laboratory results of peripheral blood are shown in Table 1. Furthermore, the tumor markers CEA, AFP, CA 19-9, and tPSA were all negative. The serological markers of hepatitis $B$ and $C$ virus were also both negative. Peritoneal fluid analysis showed a normal white blood cell count of $30 / \mathrm{mm}^{3}$ (reference range $\quad 0-180 / \mathrm{mm}^{3}$ ) with $87 \%$ lymphocytes, $11 \%$ neutrophils, and $2 \%$ monocytes. Lactate dehydrogenase (LDH) levels were $80 \mathrm{U} / \mathrm{l}$ and amylase $43 \mathrm{U} / \mathrm{l}$. Total protein levels were measured of $18 \mathrm{~g} / \mathrm{l}$ and albumin-5 g/l and glucose $6.7 \mathrm{mmol} / \mathrm{l}$. The Rivalta test was positive. No tumor cells were detected in the sample.

Table 1: Clinical laboratory results of peripheral blood from the presented patient

\begin{tabular}{|c|c|c|}
\hline Indicator & Result (\%) & Reference range (\%) \\
\hline \multicolumn{3}{|l|}{ Complete blood count } \\
\hline Hemoglobin & $\downarrow 122 \mathrm{~g} / \mathrm{l}$ & $140-180 \mathrm{~g} / \mathrm{l}$ in males \\
\hline Red blood cells & $\downarrow 3.43 \times 10^{12} / /$ & $4.5-6 \times 10^{12} / I$ \\
\hline Hematocrit & $\downarrow 0.345 \mathrm{l} / \mathrm{I}$ & $0.40-0.54 \mathrm{l} / \mathrm{I}$ \\
\hline White blood cells & $7.68 \times 10^{9} / 1$ & $3.5-10.510^{9} / /$ \\
\hline Platelets & $245 \times 10^{9} / 1$ & $140-400 \times 10^{9} / 1$ \\
\hline \multicolumn{3}{|l|}{ Differential blood count } \\
\hline Polymorphonuclear cells & $\uparrow 76.5$ & $42-70$ \\
\hline Eosinophils & 1.6 & $0-6$ \\
\hline Basophils & 0.4 & $0-2$ \\
\hline Monocytes & 6.5 & $1-14$ \\
\hline lymphocytes & $\downarrow 13.7$ & $22-48$ \\
\hline \multicolumn{3}{|l|}{ Coagulation testing } \\
\hline Prothrombin time (\%) & $\downarrow 44.3 \%$ & $70-120$ \\
\hline Prothrombin time (sec.) & $15.3 \mathrm{~s}$ & - \\
\hline INR & 1.38 & - \\
\hline Fibrinogen & $\downarrow 1.79 \mathrm{~g} / \mathrm{l}$ & $2-4.5 \mathrm{~g} / \mathrm{l}$ \\
\hline \multicolumn{3}{|c|}{ Enzyme and protein testing in serum } \\
\hline Total bilirubin & $\uparrow 39.4 \mu \mathrm{mol} / \mathrm{L}$ & $3.4-21 \mu \mathrm{mol} / \mathrm{L}$ \\
\hline Direct bilirubin & $\uparrow 18.9 \mu \mathrm{mol} / \mathrm{L}$ & $0.8-8.5 \mu \mathrm{mol} / \mathrm{L}$ \\
\hline Aspartate transaminase & $\uparrow 88 \mathrm{U} / \mathrm{l}$ & $0-50 \mathrm{U} / \mathrm{l}$ \\
\hline Alanine transaminase & $33 \mathrm{U} / 1$ & $0-45 \mathrm{U} / \mathrm{I}$ \\
\hline Lactate dehydrogenase & $335 \mathrm{U} / \mathrm{l}$ & $230-460 \mathrm{U} / \mathrm{I}$ \\
\hline Gamma-glutamyl transferase & $\uparrow 428 \mathrm{U} / \mathrm{I}$ & $0-55 \mathrm{U} / \mathrm{l}$ \\
\hline Alkaline phosphatase & $\uparrow 205 \mathrm{U} / \mathrm{l}$ & $30-120 \mathrm{U} / \mathrm{I}$ \\
\hline Cholinesterase & $\downarrow 1760 \mathrm{U} / \mathrm{I}$ & $3600-11500 \mathrm{U} / \mathrm{l}$ \\
\hline Amylase & $62 \mathrm{U} / \mathrm{I}$ & $28-100 \mathrm{U} / \mathrm{l}$ \\
\hline Lipase & $55 \mathrm{U} / \mathrm{l}$ & $0-67 \mathrm{U} / \mathrm{l}$ \\
\hline Total protein & $74 \mathrm{~g} / \mathrm{l}$ & $60-83 \mathrm{~g} / \mathrm{l}$ \\
\hline Albumin & $\downarrow 22 \mathrm{~g} / \mathrm{l}$ & $35-52 \mathrm{~g} / \mathrm{l}$ \\
\hline Creatinine & $128 \mu \mathrm{mol} / \mathrm{L}$ & $74-134 \mu \mathrm{mol} / \mathrm{L}$ \\
\hline Urea & $8 \mu \mathrm{mol} / \mathrm{L}$ & $3.2-8.2 \mu \mathrm{mol} / \mathrm{L}$ \\
\hline Uric acid & $\uparrow 478 \mu \mathrm{mol} / \mathrm{L}$ & $208-428 \mu \mathrm{mol} / \mathrm{L}$ \\
\hline \multicolumn{3}{|l|}{ Inflammatory markers } \\
\hline ESR (Westergren) & $\uparrow 74 \mathrm{~mm} / \mathrm{h}$ & $2-25 \mathrm{~mm} / \mathrm{h}$ \\
\hline C-reactive protein & $\uparrow 28 \mathrm{mg} / \mathrm{l}$ & $0-10 \mathrm{mg} / \mathrm{l}$ \\
\hline \multicolumn{3}{|l|}{ Serum immunoglobulins } \\
\hline $\lg A$ & $\uparrow 13.92 \mathrm{~g} / \mathrm{l}$ & $0.7-4.5 \mathrm{~g} / \mathrm{l}$ \\
\hline $\lg M$ & $1.83 \mathrm{~g} / \mathrm{l}$ & $0.4-2.3 \mathrm{~g} / \mathrm{l}$ \\
\hline $\lg G$ & $\uparrow 38.4 \mathrm{~g} / \mathrm{l}$ & $7-16 \mathrm{~g} / \mathrm{l}$ \\
\hline
\end{tabular}

The peritoneal fluid sample was cultured on blood agar and eosin-methylene blue (EMB) agar. After overnight incubation, smooth, grey colonies with no hemolysis on blood agar and lactose negative on the EMB agar were observed. Gram-negative polymorphic rods were seen on microscopy. Initially, the bacterium was misidentified as Sphingobacterium spiritivorum two consecutive times by the Vitek-2 Compact system (bioMerieux, France), whereas API 20 NE (bioMerieux, France) detected Elizabethkingia meningoseptica in two consecutive runs. Given these results, the pathogen was reported as E. meningoseptica to the clinical ward.

Antimicrobial susceptibility test (AST) showed sensitivity to fluoroquinolones, trimethoprim/ sulfamethoxazole, vancomycin, and resistance to piperacillin, ticarcillin/clavulanic acid, ceftazidime, amikacin, tobramycin, gentamicin, imipenem, meropenem, and colistin. The AST included the Bauer-Kirby diskdiffusion method and the E-test on Müller Hinton agar and as well as the Vitek-2 Compact system was used.

Thepatientwasgivendiuretics, hepatoprotectors, a beta-blocker, and the antibiotic levofloxacin. He was discharged 13 days of hospitalization with an improved clinical condition and laboratory markers.

The isolate was later subject to further analysis including MALDI-TOF MS system (Vitek-MS, bioMerieux, France) and gene sequencing. MALTI-TOF MS identified it as E. meningoseptica. A 1236bp 16S rRNA gene fragment $(85.9 \%)$ was sequenced with universal primers 8F/1492 Rand submitted to the EzBioCloud taxonomic database for analysis [10]. The closest resulting hit taxon was $E$. miricola DSM 14571 (T) with 99.84\% similarity (two base pairs difference). The next closest valid species was $E$. meningoseptica ( $98.38 \%$ similarity - differed by 20 bp) while some recently described species were scored with even greater similarity (Elizabethkingia bruuniana - 99.60\%; Elizabethkingia occulta - 99.4\%; and Elizabethkingia ursingii - 99.11\%). These isolates cannot be distinguished based on biochemical testing either conventional or automated.

\section{Discussion}

Elizabethkingia spp. are Gram-negative, nonspore-forming bacteria that are rarely encountered in the medical practice but are of growing clinical significance given the increasing number of reports of human infections. The genus currently includes six recognized species E. meningoseptica, Elizabethkingia anophelis, E. miricola, E. bruuniana, E. ursingii, and E. occulta [11]. Of these, the most commonly identified bacteria in clinical specimens are E. meningoseptica, E. anophelis, and E. miricola [11].

Some of the commonly used automated systems for bacterial identification fail to correctly identify the bacterium. The automated systems, such as Vitek-2 Compact and API NE, showed limited capabilities for species identification of $E$. miricola in our case, due to 
the absence of the bacterium in the detection spectrum of these tests. In the literature, several publications are reporting a successful identification of $E$. miricola using MALDI-TOF MS systems (BrukerDaltonics, Germany) and the research-use-only system of Vitek MS (bioMerieux, France) [8], [11], [12], [13]. In the presented study only the Vitek MS IVD-CE marked database was used.

Given the fact that only one bacterial pathogen was recognized on the peritoneal culture, we could exclude a traumatic paracentesis, which is also a very unusual event accounting for $0.6 \%$ of all paracenteses [14]. Furthermore, we also discarded the idea of exogenous sample contamination, because Elizabethkingia spp. are not known as commensal skin bacteria. According to the literature, nosocomial transmission has been reported in E. meningoseptica but no other patients with Elizabethkingia spp. recovered from any clinical specimen were found [15].

In $10 \%$ of all cases, spontaneous bacterial peritonitis (SBP) could be asymptomatic or atypical [14]. However, the patient did not meet the criteria of European Association for the Study of the Liver for SBP, requiring polymorphonuclear count to exceed $250 / \mathrm{mm}^{3}\left(30 / \mathrm{mm}^{3}\right.$ in the patient) [16]. Even more, the increase of the total protein in the peritoneal fluid above $10 \mathrm{~g} / \mathrm{l}$ makes it unlikely for SBP to be present (18 $\mathrm{g} / \mathrm{l}$ in the patient). On the other hand, because the LDH level in the peritoneal fluid was below $240 \mathrm{U} / \mathrm{l}$, the diagnosis of secondary bacterial peritonitis was also very unlikely. Based on the clinical presentation and the laboratory finding, liver cirrhosis class B on Pugh-Child score with bacterascites was considered the most relevant diagnosis, because bacteria were present in the peritoneal fluid in the absence of increased polymorphonuclear cells in the peritoneal sample [17]. To the best of our knowledge, this might be the first report of $E$. miricola isolated from the peritoneal cavity of a patient with liver cirrhosis and ascites.

\section{Conclusion}

Given the steadily growing importance of Elizabethkingia spp. in human pathology and the associated resistance to many antibacterial drugs, it is crucial to the microbiological laboratory to have the ability to accurately identify these bacteria to guide the most appropriate treatment and also help us better study the epidemiology of $E$. miricola infections. Furthermore, we assume that this unusual bacterium might have the potential to cause infection involving the peritoneal cavity in immunocompromised hosts.

\section{Ethical Approval}

All procedures performed in the presented study were in accordance with the ethical standards of the institution and with the 1964 Helsinki declaration and its later amendments. Written informed consent was obtained from the patient.

\section{References}

1. Li Y, Kawamura $\mathrm{Y}$, Fujiwara N, Naka T, Liu H, Huang $\mathrm{X}$, et al. Chryseobacterium miricola sp. nov., a novel species isolated from condensation water of space station mir. Syst Appl Microbiol. 2003;26(4):523-528. https://doi. org/10.1078/072320203770865828

PMid: 14666980

2. Green O, Murray P, Gea-Banacloche JC. Sepsis caused by Elizabethkingia miricola successfully treated with tigecycline and levofloxacin. Diagn Microbiol Infect Dis. 2008;62(4):430-2. https://doi.org/10.1016/j.diagmicrobio.2008.07.015

PMid: 18842380

3. Gonzalez C, Coolen-Allou N, Allyn J, Estève JB, Belmonte O, Allou N. Sepsis grave lié à un abcès pulmonaire avec bactériémie à Elizabethkingia miricola. Médecine Mal Infect. 2016;46(1):49-51. https://doi.org/10.1016/j.medmal.2015.10.011

4. Gupta P, Zaman K, Mohan B, Taneja N. Elizabethkingia miricola: $A$ rare non-fermenter causing urinary tract infection. World $J$ Clin cases. 2017;5(5):187-90. https://doi.org/10.12998/wjcc. v5. 15.187

PMid:28560237

5. Frost F, Nazareth D. Case report: First report of Elizabethkingia miricola infection in a patient with cystic fibrosis. F1000Research. 2018;7:440. https://doi.org/10.12688/ f1000research.14441.2

PMid:30079241

6. Lin JN, Lai $\mathrm{CH}$, Yang $\mathrm{CH}$, Huang $\mathrm{YH}$, Lin $\mathrm{HH}$. Complete genome sequence of Elizabethkingia miricola strain EM798-26 isolated from the blood of a cancer patient. Genome Announc. 2018;6(1):e01408-17. https://doi.org/10.1128/ genomeA.01408-17

PMid:29301886

7. Zdziarski $P$, Paściak $M$, Rogala $K$, Korzeniowska-Kowal $A$ Gamian A. Elizabethkingia miricola as an opportunistic oral pathogen associated with superinfectious complications in humoral immunodeficiency: A case report. BMC Infect Dis. 2017;17(1):763. https://doi.org/10.1186/s12879-017-2886-7

8. Kenna DT, Fuller A, Martin K, Perry C, Pike R, Burns PJ, et al. rpoB gene sequencing highlights the prevalence of an $E$. miricola cluster over other Elizabethkingia species among UK cystic fibrosis patients. Diagn Microbiol Infect Dis. 2018;90(2):109-14. https://doi.org/10.1016/j.diagmicrobio.2017.10.014

PMid:29174734

9. Choi MH, Kim M, Jeong SJ, Choi JY, Lee IY, Yong TS, et al. Risk factors for Elizabethkingia acquisition and clinical characteristics of patients, South Korea. Emerg Infect Dis. 2019;25(1):42-51. https://doi.org/10.3201/EID2501.171985 PMid:30561316

10. Yoon SH, Ha SM, Kwon S, Lim J, Kim Y, Seo H, et al. Introducing EzBioCloud: A taxonomically united database of $16 \mathrm{~S}$ rRNA 
gene sequences and whole-genome assemblies. Int J Syst Evol Microbiol. 2017;67(5):1613-7. https://doi.org/10.1099/ ijsem.0.001755

PMid:28005526

11. Lin JN, Lai $\mathrm{CH}$, Yang $\mathrm{CH}$, Huang $\mathrm{YH}$. Elizabethkingia infections in humans: From genomics to clinics. Microorganisms. 2019;7(9):295. https://doi.org/10.3390/ MICROORGANISMS7090295

\section{PMid:31466280}

12. Eriksen $\mathrm{HB}$, Gumpert $\mathrm{H}$, Faurholt $\mathrm{CH}$, Westh $\mathrm{H}$. Determination of Elizabethkingia diversity by MALDI-TOF mass spectrometry and whole-genome sequencing. Emerg Infect Dis. 2017;23(2):320-323. https://doi.org/10.3201/eid2302.161321 PMid:28098550

13. Cheng $\mathrm{YH}$, Perng CL, Jian MJ, Lee SY, Sun JR, Shang HS. Multicentre study evaluating matrix-assisted laser desorption ionization-time of flight mass spectrometry for identification of clinically isolated Elizabethkingia species and analysis of antimicrobial susceptibility. Clin Microbiol Infect. 2019;25(3):340-5. https://doi.org/10.1016/j.cmi.2018.04.015

PMid:29689427
14. Runyon BA. Polymicrobial bacterascites. A unique entity in the spectrum of infected ascitic fluid. Arch Intern Med. 1986;146(11):2173-5. https://doi.org/10.1001/archinte.146.11.2173 PMid:3778046

15. Jean SS, Lee WS, Chen FL, Ou TY, Hsueh PR. Elizabethkingia meningoseptica: An important emerging pathogen causing healthcare-associated infections. J Hosp Infect. 2014;86(4):244-9. https://doi.org/10.1016/j.jhin.2014.01.009 PMid:24680187

16. Ginès $P$, Angeli $P$, Lenz $K$. EASL clinical practice guidelines on the management of ascites, spontaneous bacterial peritonitis, and hepatorenal syndrome in cirrhosis. J Hepatol. 2010;53(3):397-417. https://doi.org/10.1016/j.jhep.2010.05.004 PMid:20633946

17. Rimola A, García-Tsao G, Navasa M, Piddock LJ, Planas R, Bernard $B$, et al. Diagnosis, treatment and prophylaxis of spontaneous bacterial peritonitis: A consensus document J Hepatol. 2000;32(1):142-53. https://doi.org/10.1016/ S0168-8278(00)80201-9

PMid:10673079 